International Journal of Engineering \& Technology, $7(3.2)(2018)$ 376-381
International Journal of Engineering \& Technology
WPC
Website www.sciencepubco.com/index.php/IJET
Research paper

\title{
Effects of Concrete Core Technological Defects on the Strength of Tube Confined Concrete Elements
}

\author{
Oleksandr Semko ${ }^{1}$, Olga Gukasian ${ }^{2 *}$, Serhii Skliarenko ${ }^{3}$

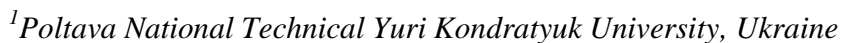 \\ ${ }^{2}$ Poltava National Technical Yuri Kondratyuk University, Ukraine \\ ${ }^{3}$ Poltava National Technical Yuri Kondratyuk University, Ukraine \\ *Corresponding Author E-Mail: Olg.Gukasyan@Gmail.Com
}

\begin{abstract}
.
The paper sums up a series of experimental studies describing the influence of most types of concreting common defects, such as core weakening: weak compression inclusions, voids, height heterogeneity of concrete. The basis of the experimental study is the research on the concrete core production conditions influence on tube confined concrete elements and the change in physical and mechanical characteristics of the elements. The concrete strength is estimated based on the results of the study of specially shaped samples with given dimensions. According to the results of concreting samples with different types of modeled defects (abnormalities) inspection, the most dangerous damages of the concrete core were identified and different variants of the height strength retrogression of the elements under study were analyzed. As a result, the degree and type of damage to the tube confined concrete elements core of the samples, which affect the fracture pattern, was established.
\end{abstract}

Keywords: concrete, ash and slag, compressive strength, water absorption

\section{Introduction}

Today, tube confined concrete structures became widespread in construction processes. They comprise a steel tube (or made of other materials) filled with concrete. In such structural elements, the tube casing plays the role of external reinforcement (longitudinal and lateral) and at the same time is an irremovable formwork, which significantly increases the strength and reliability of compression elements, as well as the speed and technology of their installation. The concrete quality in tube confined concrete elements depends heavily on the production process, as due to rough concreting conditions (fitting the concrete mixture into closed space of the tube casing), and at times relatively low production culture of large concrete batches, there are risks of concrete core defects formation (disintegration, cavities, voids, cracks, variability of concrete strength throughout the height of an element, etc.). Besides, the presence of external reinforcement (tube casing, which simultaneously performs the function of irremovable formwork) complicates the process of controlling the concrete strength during the production and operation of tube confined concrete structures. Detecting and taking into account formation patterns of heterogeneous core concrete strength of such elements throughout the height requires special attention when assessing the strength and ensuring the design level of tube confined concrete constructions reliability.

\section{Overview of the Latest Research Sources and Publications}

In tube confined concrete elements, the presence of a steel tube casing, which plays the role of an irremovable formwork, and the outer longitudinal and lateral reinforcement at the same time, is one of the tube confined concrete constructions advantages. For example, with a relatively small cross-section, such constructions are able to withstand great stress $[1,2]$, in such constructions concrete, due to the volumetric stress state, takes longitudinal stress which significantly exceeds its prism strength.

Numerous studies [3, 4] have established that the isolation of concrete mixture in the tube casing from the external environment enhances the concrete properties strength and homogeneity. This is because expansion of the concrete takes place instead of the expected shrinkage and the strength of concrete increases by $10 \ldots 15 \%$, which lasts for many years and creates favorable conditions for operation under load. Creep of concrete, which is in a tube-casing structural element (composite material), is lower than conventional reinforced concrete constructions and has less significant impacts on the modulus of concrete deformation over time.

Among the key factors, determining the strength of tube confined concrete elements, it is necessary to highlight technology factors. Researching the impact of technology factors on strength and reliability are particularly important for structural elements, where concrete is placed in a closed space, that is, for pillars, which have relatively small cross-sectional dimensions and substantial lengths. The quality of tube confined concrete pillars production, from the technological point of view, is primarily due to the filling of the tube casing with concrete and possible formation of technological defects of concrete related to it: formation of scabbing, cavities, sections with different strengths, etc. For the same reasons, it is almost impossible to control the quality of concrete directly at the production site.

It is obvious that the possible internal defects (concreting abnormalities) have a more significant effect on the performance of compression elements, for which the role of concrete compressed zone is more important. Considering tube confined concrete con- 
structions from this point of view, it is necessary to pay attention to the technological features of concrete production, as a characteristic feature of tube confined concrete constructions is the existence of certain difficulties connected with the concrete mix placement and consolidation in the closed space of the steel tube casing. Defects of tube confined concrete pillars concreting should include concrete mixture disintegration, formation of cavities and scabbing on the core and casing contact surface, heterogeneity of the structure and physical and mechanical properties of the concrete in height of the sample, etc. However, numerous studies conducted by L.I. Storozhenko O.V. Semko, O.P. Voskobiinyk, D.A. Yermolenko and other indicate the lack of disintegration in the concrete mixture even when falling from a significant (10-15 m) height and homogeneity of the concrete core macrostructure when concrete is placed vertically. Conversely, in the case of tubes inclined concreting at prefabricate plants on platform vibrators with a smooth feeding of concrete mixes, cases of formation of cavities occur [5, 6].

Research on concreting conditions effects and related to them defects in the concrete core on the load bearing capacity and stress-strain state of tube confined concrete elements $[7,8]$ indicate possible significant reduction in the load bearing capacity of tube confined concrete pillars with artificially created voids or insufficient strength of concrete used for modeling concreting defects.

Thus, a special group of structural elements containing concrete in a closed space production defects comprises concreting abnormalities that in the established typology of tube confined concrete structures damage and defects [9-11] are classified by the nature of emergence as a group of technological defects and by localization as internal defects of the core. Internal defects (concreting abnormalities) affect pillars more significantly, for which the role of concrete compressed zone is more important.

\section{Defining Parts of General Problem which were Not Yet Investigated}

The concrete quality in tube confined concrete elements depends on the technology of their production, as due to the existence of complicated concreting conditions - concrete placement into the tube casing closed space, there are risks of concrete core defects formation (disintegration, cavities, voids, cracks, variability of strength in the height of the sample and other). Besides, the presence of external reinforcement (tube casing, which at the same time performs the function of irremovable formwork) complicates the process of controlling the concrete strength. Detection and consideration of consistent patterns in formation of heterogeneous height concrete strength requires special attention during the probabilistic analysis of performance and evaluation of reliability indicators of elements in general. Therefore, the issue of studying the causes of concrete defects formation and its possible heterogeneity in structural elements zones, which in turn requires the development of a rational concreting technology, is one of the priority directions of research on tube confined concrete elements today.

However, concrete mix production and compaction technology has a significant impact on the strength of structural elements containing concrete, especially in complicated concreting conditions, and the necessity to place concrete in a closed space (lateral reinforcement pillar), which is typical for tube confined concrete constructions, especially on the construction site. All these factors lead to the emergence of possible production (concreting) defects (abnormalities) and concrete core heterogeneity in terms of the structural tube confined concrete element volume, which requires the study of a number of technological factors (physical and mechanical properties of the concrete mixture, methods of placing it in the tube casing, methods of consolidation and the concrete hardening conditions, etc.) influence. Thus, the study of concreting technology impact on the concrete core strength of tube confined concrete elements is an urgent scientific issue that must be dealt with.

\section{Aims and Objectives}

Therefore, the issue of the reasons for defects formation in the concrete core and its possible heterogeneity in the areas of constructional elements is one of the priority areas for the research on tube confined concrete structures. And the study of tube confined concrete elements strength, depending on the impact of concreting technology, is an important scientific problem that needs to be addressed.

\section{Results}

Experimental research on the most common types of concreting defects influence on tube confined concrete elements and to determine their influence on the strength of a structural element. As the main defects characteristic for the concrete core are the weakening of the core, the inclusion of "weak" concrete, the presence of voids, the heterogeneity of concrete in height.

Experimental research in accordance with the adopted program was conducted in two stages:

- "CFST" series - for studying the influence of artificially created defects on the strength of the concrete core of short tube confined concrete elements in the steel tube casing;

- "CS" series - for studying the influence of tube confined concrete elements production technology on the variability of concrete cylinder samples strength in height.

The paper provides analysis of the experimental research results on influence of concreting technology on tube confined concrete elements with different types of the most common defects such as: concrete strength height heterogeneity of the sample ("CFSTk" tube confined concrete samples series and "CS" concrete samples series) and the presence of voids and cavities ("CFSTp" series). Such an approach allows arranging possible defects of the concrete core by the degree of their impact on the strength of tube confined concrete structures, and serve as the basis for further development of methodology for calculating and assessing technical condition of such type of construction elements, as well as providing recommendations for optimizing the technology of tube confined concrete production. For creating voids and cavities (artificial defects) expanded polystyrene cubes, carefully measured and cut, were used.

During the production of the "CS" samples series, the most common types of technological defects in the concrete core were modeled, in particular height heterogeneity of the concrete strength of a sample ("CFSTk" series) and the presence of voids and cavities ("CFSTp" series). Short tube confined concrete elements (l=4d) were studied, made of a steel electric-welded cold-sized tube with an outside diameter $\mathrm{D}=108 \mathrm{~mm}$, wall thickness $\mathrm{t}=3.5 \mathrm{~mm}$, filled with heavy-weight concrete of various grades (C16/20 and $\mathrm{C} 30 / 35$ ) height along the sample for modeling technology defects in concreting on the construction site. Filling tube confined concrete samples with concrete was carried out in accordance with different schemes: throughout the height with the same strength concrete (CFSTk-1 and CFSTk-2), filling with different strength concrete by $1 / 2$ of the height (CFSTk-3 and CFSTk-4), filling with concrete of different strength by $1 / 4$ of the height at the sample ends (CFSTk-5 and CFSTk-6), different strength concrete by $1 / 3$ of the sample height (CFSTk-7, CFSTk-8, CFSTk-9, CFSTk-10), Figure 1, Figure 2.

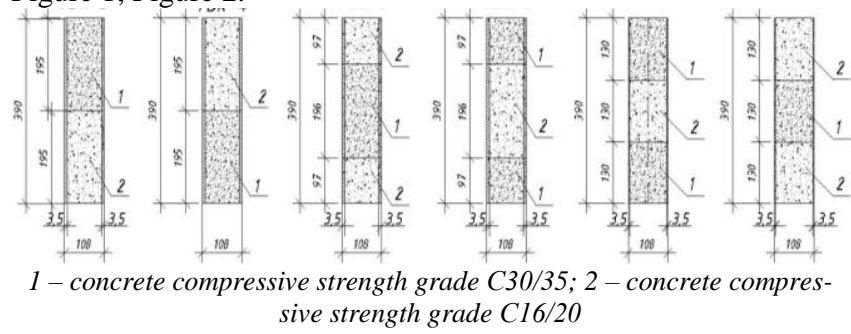

Fig. 1: Scheme of experimental samples of tube confined concrete elements concrete filling with modeled concrete core technological defects in 
the form of heterogeneity of the concrete strength distribution height along the sample ("CFSTk" series)

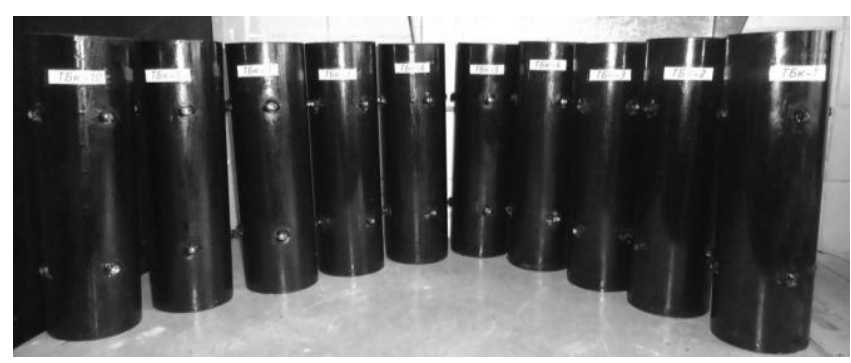

Fig. 2: Outside appearance of tube confined concrete elements samples of "CS" series.

The study of the change in the tube confined concrete elements characteristics due to the presence of technological defects was carried out by concreting the CS-casings with artificially created weakening (Fig. 3), a cross-section of $30 \times 30 \mathrm{~mm}$, located near the tube wall (CFSTp-1 and CFSTp-2) and in the center of the sample (CFSTp-3 and CFSTp-4) throughout its height. In addition, one sample (CFSTp-5) was produced with artificial weakening in the form of a cavity sized $30 \times 30 \times 60 \mathrm{~mm}$, placed half its height near the tube wall.

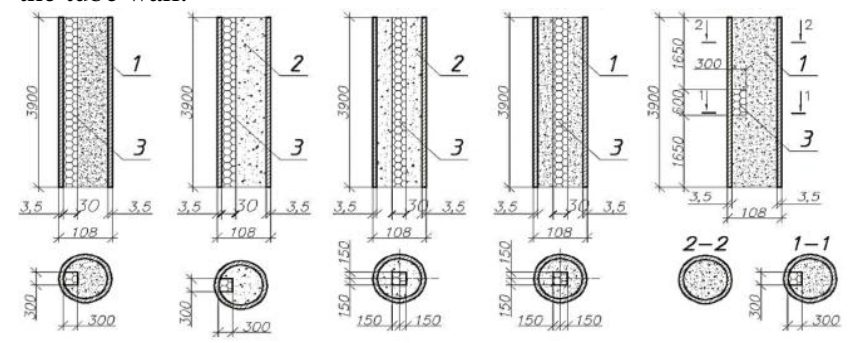

1 - concrete compressive strength grade C30/35;2 - concrete compressive strength grade C16/20; 3 - voids, artificially created with expanded polystyrene.

Fig. 3: Structure of tube confined concrete pillars study samples ("CFSTp" study samples)

A series of cylindrical samples ("CS" series) with a height of $200 \mathrm{~mm}$ (Fig. 6 b) and 400mm (Fig. 6 a) was made to study the heterogeneity of the height strength characteristics. During the experiment, the variation parameter was the durability of concrete on two levels: concrete with cement weight of $250 \mathrm{~kg} / \mathrm{m}^{3}$ and 450 $\mathrm{kg} / \mathrm{m}^{3}$, while the average weight of cement for $1 \mathrm{~m}^{3}$ for all variants of the samples under study was $350 \mathrm{~kg} / \mathrm{m}^{3}$. To mark the concrete layer with less strength, a pigment was added to the concrete mixture. The strength of concrete was studied using two methods: compressive strength test and abrasive hardness test.

The first part of the experimental studies describes the results of the compressive strength tests of the "CFSTk" and "CFSTp" tube confined concrete samples. During the experiment, two forces were captured which meet different criteria for loss bearing capacity of short axially compressed tube confined concrete samples: $\mathrm{N} 1$ is the force corresponding to longitudinal deformations which appeared when the tube-casing steel flow limit was reached; N2 is the maximum compressive force that the sample can withstand. a)
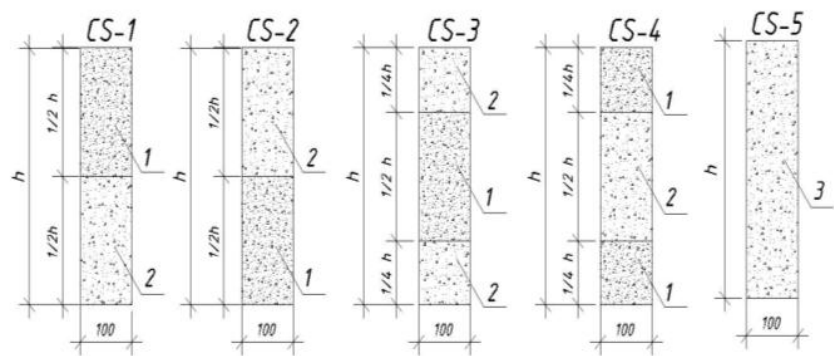

b)

CS-6

CS-7
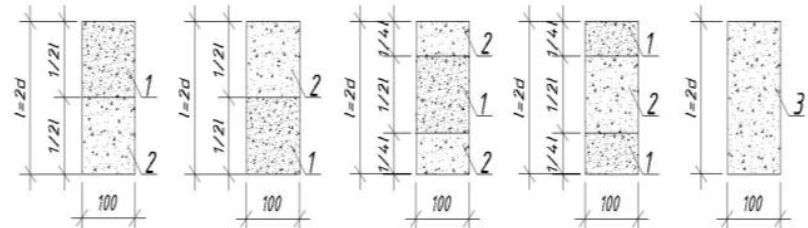

1 - concrete with weight of cement $450 \mathrm{~kg}$ per $1 \mathrm{~m}^{3} ; 2$-concrete with weight of cement $250 \mathrm{~kg}$ per $1 \mathrm{~m}^{3} ; 3$ - concrete with weight of cement 350 kg per $1 \mathrm{~m}^{3}$.

Fig. 4: Samples of «CS» series concreting scheme of height $l=4 d$ and $l=$ $2 d$.

a) samples of «CS» series with $400 \mathrm{~mm}$ height $(l=4 d)$; b) samples of «CS» series with $200 \mathrm{~mm}$ height $(l=4 d)$.

The experiment samples of the "CFSTk" series "CFSTk2...CFSTk-10" tube casing flow limit (N1) varied from 330 to 386 $\mathrm{kN}$, which is $12.4 \%$, and the bearing capacity (N2) $\square$ value varied from 432 to $514 \mathrm{kN}$ (15.9\%), except for the sample CFSTk-1 (where $\mathrm{N} 1$ is $575 \mathrm{kN}$, and $\mathrm{N} 2$ is $850 \mathrm{kN}$ ). The maximum carrying capacity valuesof the "CFSTk" sample series (N2) were 19...29\% higher than the load values at the beginning of the tube flow (N1). On average, $\Delta \mathrm{N}$ (difference between $\mathrm{N} 1$ and N2) was $25 \%$. Experiment samples bearing capacity of the "CFSTp" series has a larger range of values: $\mathrm{N} 1$ varied from 318 to $414 \mathrm{kN}$, which is $23.2 \%$, $\mathrm{N} 2 \square$ values varied from 330 to $480 \mathrm{kN}(31.2 \%)$. For example, the CFSTp-5 sample bearing capacity by $31 \%$ exceeds the capacity of the CFSTp-3 sample. That is, the deterioration of the sample occurs in the location of concrete core (in the middle or at the ends) weakening by formation of corrugations in the tube-casing (Table 3 ), because, in this case, the effect of increasing the local strength of the steel casing, typical for tube confined concrete elements, practically disappears. Based on the study of samples strength heterogeneity of the "CFSTk" and "CFSTp" series, it can be concluded that the lowest bearing capacity is typical for samples with artificially created core defects in the form of voids located in the center and near the sample wall (Figure 5).

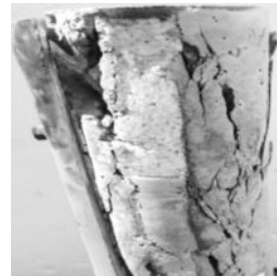

CFSTp-1

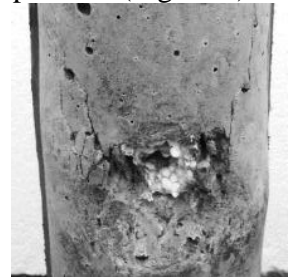

CFSTp-5

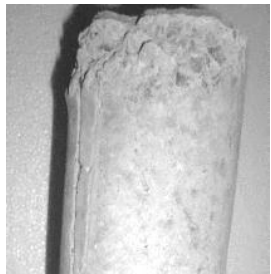

CFSTk-2
Fig. 5: Model illustrations of concrete core deformations after tests.

Experiment samples of the "CFSTk" series have the same fracture pattern, and "CFSTp" samples, when losing bearing capacity, are distorted in the location of cavities. The difference between N1 and $\mathrm{N} 2$ is characterized by the value of $\Delta \mathrm{N}$ equal to:

$\Delta N=\frac{N_{2}-N_{1}}{N_{2}} \cdot 100 \%$

Table 1: Test results of experimental tube confined concrete elements samples with concrete core defects (weakenings)

\begin{tabular}{|c|c|c|c|}
\hline \multirow{2}{*}{$\begin{array}{l}\text { Sample name- } \\
\text { code }\end{array}$} & \multicolumn{2}{|c|}{ Critical force } & \multirow{2}{*}{ Sample fracture pattern } \\
\hline & $N_{l}, \mathbf{к H}$ & $N_{2}, \mathbf{\kappa H}$ & \\
\hline 1 & 2 & 3 & 4 \\
\hline \multicolumn{4}{|c|}{ CFSTk series } \\
\hline CFSTk-1 & 575 & 850 & \multirow{2}{*}{$\begin{array}{l}\text { Corrugation formation at the } \\
\text { end of the sample and center } \\
\text { line bending }\end{array}$} \\
\hline CFSTk-2 & 330 & 454 & \\
\hline CFSTk-3 & 345 & 484 & \multirow{2}{*}{$\begin{array}{l}\text { The destruction occurred in } \\
\text { the zone of the concete } \\
\text { strength weakening and } \\
\text { corrugations were formed }\end{array}$} \\
\hline CFSTk-4 & 368 & 484 & \\
\hline CFSTk-5 & 384 & 514 & $\begin{array}{l}\text { Corrugations were formed } \\
\text { and expansion in the area } \\
\text { with concrete with less } \\
\text { strength }\end{array}$ \\
\hline CFSTk-6 & 342 & 432 & Corrugations were formed on \\
\hline
\end{tabular}




\begin{tabular}{|c|c|c|c|}
\hline & & & $\begin{array}{l}\text { the top and bottom (at the } \\
\text { ends) of the sample }\end{array}$ \\
\hline CFSTk-7 & 338 & 484 & \multirow{2}{*}{$\begin{array}{l}\text { Inward bend and corrugation } \\
\text { in the middle of the sample }\end{array}$} \\
\hline CFSTk-8 & 358 & 498 & \\
\hline CFSTk-9 & 386 & 480 & \multirow{2}{*}{$\begin{array}{l}\text { Corrugations were formed in } \\
\text { the top and bottom areas of } \\
\text { the sample }\end{array}$} \\
\hline CFSTk-10 & 362 & 476 & \\
\hline \multicolumn{4}{|c|}{ CFSTp series } \\
\hline CFSTp-1 & 332 & 436 & \multirow{2}{*}{$\begin{array}{l}\text { Corrugations were formed in } \\
\text { the top and middle areas of } \\
\text { the sample, fractures can be } \\
\text { observed in the concrete core }\end{array}$} \\
\hline CFSTp-2 & 320 & 376 & \\
\hline CFSTp-3 & 318 & 330 & \multirow{2}{*}{$\begin{array}{c}\text { Corrugations were formed in } \\
\text { the top area, but no fractures } \\
\text { can be observed in the } \\
\text { concrete core }\end{array}$} \\
\hline CFSTp-4 & 414 & 450 & \\
\hline CFSTp-5 & 408 & 480 & $\begin{array}{c}\text { Corrugations and a dimple at } \\
\text { the location of a cavity were } \\
\text { formed }\end{array}$ \\
\hline
\end{tabular}

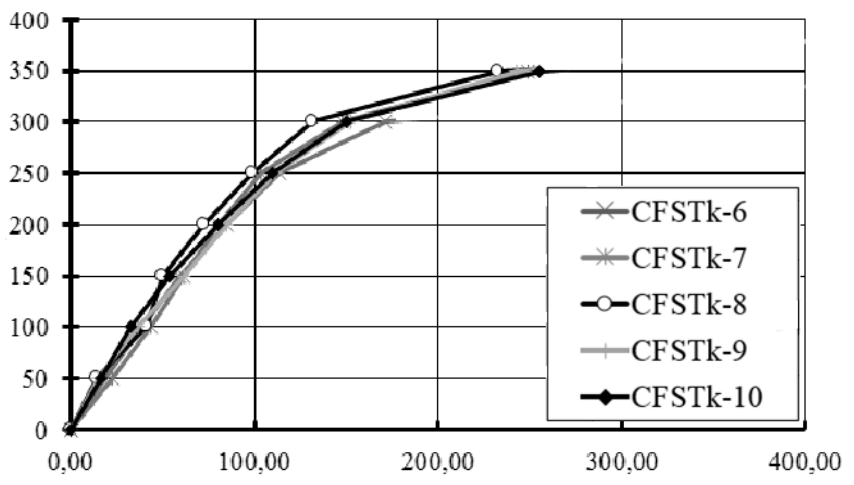

The presence of defects in concreting in the form of cavities in the "CFSTp" series of samples, which during the experimental studies were modeled by the inclusion of foamed polystyrene inclusions, leads to a decrease in the casing effect, and to the formation of additional eccentricities, due to which there is a significant reduction in the bearing capacity of pillars, especially the relation of forces $\mathrm{N} 2 / \mathrm{N} 1$. That is, tube confined concrete structures with such a type of defects are characterized by a much less ductile performance (Figure 6).

At the beginning of stress, dependence is close to linear, and then graphs turn into curved, which is explained by peculiarities of steel and concrete deformation. Lateral deformations at small loads develop insignificantly, and when approaching the limit state they increase largely. This indicates an increase in lateral stress. That is, the volume of the sample decreased at the beginning of stress, and eventually increased, exceeding the starting value. The beginning of the sample volume roughly coincides with the beginning of the longitudinal tube flow.

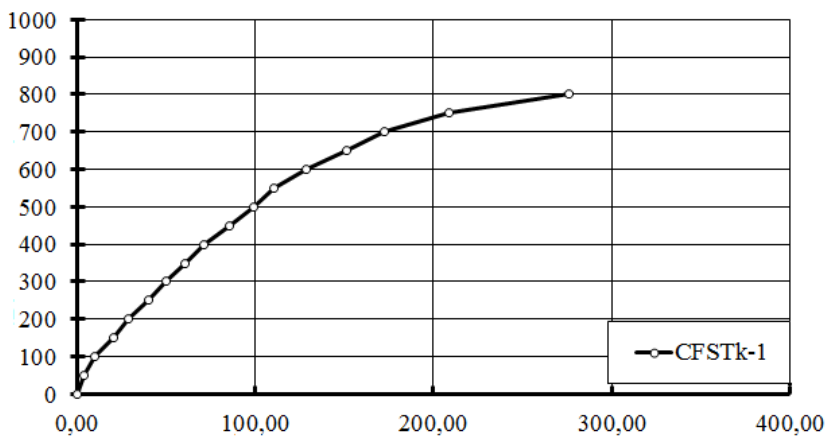

a) longitudinal deformations of CFSTk-1 sample

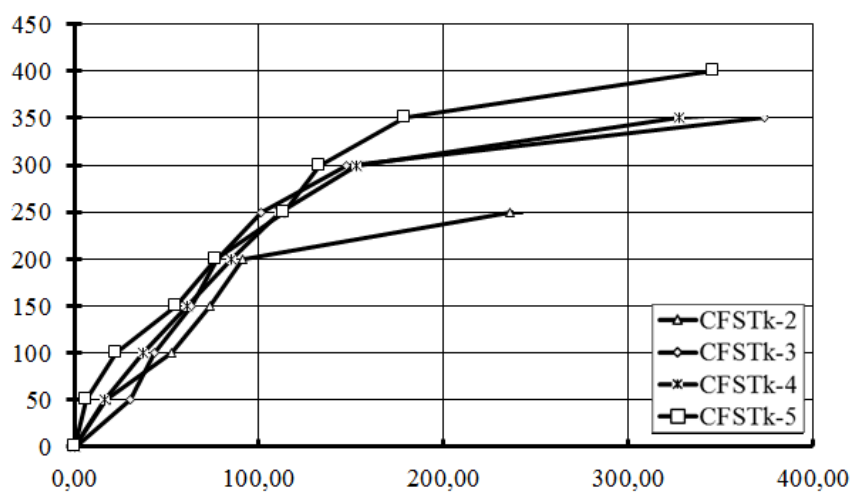

b) longitudinal deformations of CFSTk-2...CFSTk-5 samples

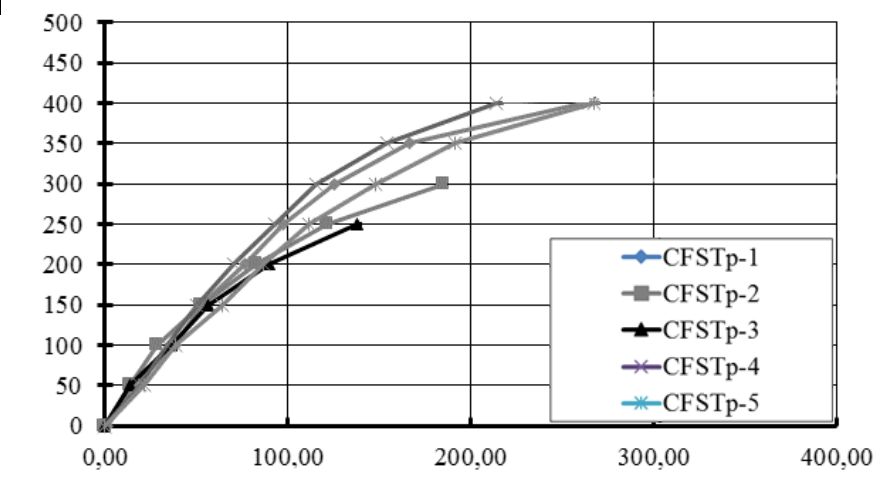

d) longitudinal deformations of CFSTp-1...CFSTp-5 samples

Fig. 6: Dependence of longitudinal deformations of samples on stress

Longitudinal deformations of the samples under study indicate elastic behavior of samples up to $\mathrm{N} 1$ and plastic behavior from $\mathrm{N} 1$ to $\mathrm{N} 2$.

The type (unlike the parameters) of concrete core artificially created damages of the tube confined concrete samples under study significantly affects their bearing capacity. For example, the heterogeneity of the height strength of the sample leads to a decrease in the bearing capacity of a tube confined concrete element to the extent from 10 to $15 \%$, which indicates a decrease in the share of concrete core defects impact in tube confined concrete elements with a steel tube casing.

The presence of defects in the concrete structure in the form of cavities and voids leads to the concentration of stresses in the weakening location, which leads to a decrease in the concrete strength with the axial compression of the element. Regardless of the defects size in the form of cavities and their location, the total strength of tube confined concrete elements is reduced to $30 \%$ of the designed strength.

The second part of the experimental studies describes the results of the compressive strength test and the non-destructive test method of the "CS" series. To determine the height strength homogeneity of a concrete sample, a testing methodology was developed. Determination of height strength variability of concrete samples-cylinders of the "CS" series by a non-destructive method (abrasive hardness test) was performed on two samples of each series (Table 2).

Along the height, the samples (200 mm and $400 \mathrm{~mm})$, conventionally divided into 5 or 10 equal fragments, were studied according to the non-destructive method, and the average strength value of the fragment was found.

For each concreting layer, an average strength value $f 1$ (cement weight per $1 \mathrm{~m}^{3}$ of concrete of $450 \mathrm{~kg}$ ), $f 2$ (cement weight per 1 $\mathrm{m}^{3}$ of concrete of $250 \mathrm{~kg}$ ), and $f 3$ (cement weight per $1 \mathrm{~m}^{3}$ of concrete of $350 \mathrm{~kg}$ ) was calculated, then samples were destructed by the pressure test machine $\left(f_{c, c u l}\right)$. It should be noted that samples of the CS-3 and CS- 8 series (with weakening at the end of the sample by $1 / 4 l$ ) have the highest average compressive strength values, which are up to $8 \ldots 10 \%$ higher than the testing specimens (series CS-5 and CS-10). For other samples, the decrease in average 
strength value of samples is typical, from the average of $14 \%$ to $22 \%$.

Samples of the CS-3 series have the maximum average strength values of the two specimens (determined by the non-destructive method), with increased strength of concrete in the middle of the sample. Other samples with a height of $400 \mathrm{~mm}$ have a value of 20 to $21 \%$ lower than the $\mathrm{C}-3$. It should be noted that greater difference between the values of strength determined by the destructive and non-destructive methods is peculiar for samples where the upper half is concreted with lower strength concrete (a series of CS-2 samples). The fracture pattern of "CS" series samples with $4 \mathrm{~d}$ height after the compressive strength test is presented in Figure 7.

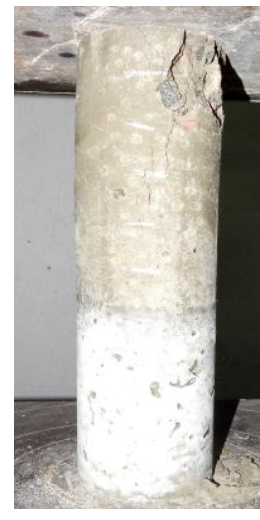

CS-2

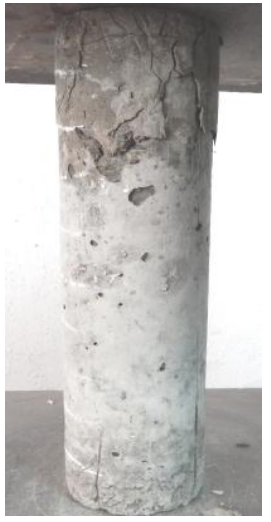

CS-3

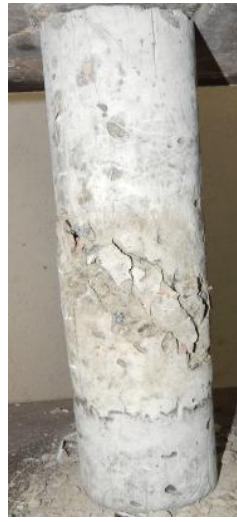

CS-4
Fig. 7. Fracture pattern of "CS" series samples after testing

This fracture pattern is also typical for concrete samples of "CS" series with $2 \mathrm{~d}$ height.

According to the tests results, the coefficient of the concrete compressive strength variation of the "CS" series was calculated: $\mathrm{V}_{\text {com }}$ $=18 \%$, and if the samples were divided according to height: $4 \mathrm{~d}$ and $2 \mathrm{~d}$, then the values were $22 \%$ and $14 \%$ respectively. The average strength value, defined by the non-destructive method, $\mathrm{V}_{\text {non- }}$ $=10 \%$. In this case, if the samples are divided according to their height, then for samples with $4 \mathrm{~d}$ and $2 \mathrm{~d}$ height the variation coefficient is $5 \%$ and $13 \%$ respectively.

Table 2. Results of concrete strength tests of cylindric samples

\begin{tabular}{|c|c|c|c|c|c|}
\hline \multirow[t]{2}{*}{ 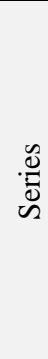 } & \multirow{2}{*}{$\begin{array}{l}\text { Methodol- } \\
\text { ogy of } \\
\text { samples } \\
\text { concreting } \\
\text { and loca- } \\
\text { tion of } \\
\text { concrete } \\
\text { with lower } \\
\text { strength } \\
\text { value }\end{array}$} & \multicolumn{2}{|c|}{$\begin{array}{l}\text { Methods of concrete } \\
\text { strength testing }\end{array}$} & \multicolumn{2}{|c|}{$\begin{array}{l}\text { Tests results on } \\
\text { the strength of } \\
\text { concrete layers } \\
\text { of the sample } \\
\text { and compressive } \\
\text { strength tests }\end{array}$} \\
\hline & & $\begin{array}{l}\text { Testing } \\
\text { method }\end{array}$ & $\begin{array}{l}\text { Strength } \\
\text { characteris- } \\
\text { tics }\end{array}$ & $\begin{array}{c}\text { Sample } \\
1 \\
\mathrm{MPa}\end{array}$ & $\begin{array}{l}\text { Sam- } \\
\text { ple } 2 \\
\text { MPa }\end{array}$ \\
\hline 1 & 2 & 3 & 4 & 5 & 6 \\
\hline \multirow{2}{*}{ U่ } & \multirow{2}{*}{$\begin{array}{c}\text { Concrete } \\
\text { strength } \\
\text { weakening } \\
\text { in } 1 / 2 l \\
\text { (bottom of } \\
\text { the sample) }\end{array}$} & $\begin{array}{c}\text { Non- } \\
\text { destructive } \\
\text { method }\end{array}$ & $\begin{array}{l}f_{1} \\
f_{2}\end{array}$ & $\begin{array}{l}41,1 \\
20,7\end{array}$ & $\begin{array}{l}41,0 \\
21,8 \\
\end{array}$ \\
\hline & & $\begin{array}{l}\text { Випроб. } \\
\text { на стиск }\end{array}$ & $f_{\text {c,cul }}$ & 20,49 & 21,42 \\
\hline \multirow{2}{*}{$\begin{array}{r}\tilde{y} \\
\tilde{u}\end{array}$} & \multirow{2}{*}{$\begin{array}{c}\text { Concrete } \\
\text { strength } \\
\text { weakening } \\
\text { in } 1 / 2 l \text { (top } \\
\text { of the sam- } \\
\text { ple) }\end{array}$} & $\begin{array}{c}\text { Non- } \\
\text { destructive } \\
\text { method }\end{array}$ & $\begin{array}{l}f_{2} \\
f_{1}\end{array}$ & $\begin{array}{l}20,6 \\
40,7\end{array}$ & $\begin{array}{l}22,2 \\
43,8 \\
\end{array}$ \\
\hline & & $\begin{array}{l}\text { Випроб. } \\
\text { на стиск }\end{array}$ & $f_{\mathrm{c}, \mathrm{cul}}$ & 18,37 & 20,06 \\
\hline \multirow{2}{*}{$\hat{\tilde{u}}$} & \multirow{2}{*}{$\begin{array}{l}\text { Concrete } \\
\text { strength } \\
\text { weakening } \\
\text { in } 1 / 4 l \\
\text { (ends of the }\end{array}$} & $\begin{array}{c}\text { Non- } \\
\text { destructive } \\
\text { method }\end{array}$ & $\begin{array}{l}f_{2} \\
f_{1} \\
f_{2}\end{array}$ & $\begin{array}{l}20,9 \\
46,2 \\
22,7\end{array}$ & $\begin{array}{l}21,4 \\
45,9 \\
22,8\end{array}$ \\
\hline & & $\begin{array}{l}\text { Compres- } \\
\text { sive test }\end{array}$ & $f_{\mathrm{c}, \mathrm{cul}}$ & 31,62 & 22,05 \\
\hline
\end{tabular}

\begin{tabular}{|c|c|c|c|c|c|}
\hline & sample) & & & & \\
\hline \multirow{4}{*}{ घै } & \multirow{4}{*}{$\begin{array}{c}\text { Concrete } \\
\text { strength } \\
\text { weakening } \\
\text { in } 1 / 2 l \\
\text { (middle of } \\
\text { the sample) }\end{array}$} & Non- & $\overline{f_{l}}$ & 42,1 & 40,7 \\
\hline & & destructive & $f_{2}$ & 21,8 & 22,9 \\
\hline & & method & $f_{l}$ & 41,6 & 41,6 \\
\hline & & $\begin{array}{l}\text { Compres- } \\
\text { sive test }\end{array}$ & $f_{\mathrm{c}, \mathrm{cul}}$ & 13,45 & 25,71 \\
\hline \multirow{2}{*}{$\ddot{n}$} & \multirow{2}{*}{$\begin{array}{l}\text { Concrete of } \\
\text { the same } \\
\text { strength } \\
\text { throughout } \\
\text { the height }\end{array}$} & $\begin{array}{c}\text { Non- } \\
\text { destructive } \\
\text { method }\end{array}$ & $f_{3}$ & 33,7 & 32,1 \\
\hline & & $\begin{array}{c}\text { Compres- } \\
\text { sive test }\end{array}$ & $f_{\mathrm{c}, \mathrm{cul}}$ & 24,76 & 24,39 \\
\hline \multirow{2}{*}{$\begin{array}{l}0 \\
1 \\
\text { ñ }\end{array}$} & \multirow{2}{*}{$\begin{array}{l}\text { Concrete } \\
\text { strength } \\
\text { weakening } \\
\text { in } 1 / 2 l \\
\text { (bottom of } \\
\text { the sample) }\end{array}$} & $\begin{array}{c}\text { Non- } \\
\text { destructive } \\
\text { method }\end{array}$ & $\begin{array}{l}f_{1} \\
f_{2}\end{array}$ & $\begin{array}{l}38,7 \\
18,1\end{array}$ & $\begin{array}{c}36,4 \\
17,6\end{array}$ \\
\hline & & $\begin{array}{l}\text { Compres- } \\
\text { sive test }\end{array}$ & $f_{\mathrm{c}, \mathrm{cul}}$ & 26,32 & 25,14 \\
\hline \multirow{3}{*}{ चे } & \multirow{3}{*}{$\begin{array}{c}\text { Concrete } \\
\text { strength } \\
\text { weakening } \\
\text { in } 1 / 2 l \text { (top } \\
\text { of the sam- } \\
\text { ple) }\end{array}$} & Non- & $f_{2}$ & 17,6 & 15,7 \\
\hline & & $\begin{array}{c}\text { destructive } \\
\text { method }\end{array}$ & $f_{l}$ & 34,6 & 33,3 \\
\hline & & $\begin{array}{c}\text { Compres- } \\
\text { sive test }\end{array}$ & $f_{\mathrm{c}, \mathrm{cul}}$ & 27,80 & 26,27 \\
\hline \multirow{4}{*}{$\begin{array}{l}\infty \\
1 \\
\omega^{2}\end{array}$} & \multirow{4}{*}{$\begin{array}{c}\text { Concrete } \\
\text { strength } \\
\text { weakening } \\
\text { in } 1 / 4 l \\
\text { (ends of the } \\
\text { sample) } \\
\end{array}$} & Non- & $f_{2}$ & 21,2 & 22,5 \\
\hline & & destructive & $f_{l}$ & 39,7 & 38,0 \\
\hline & & method & $f_{2}$ & 19,7 & 15,7 \\
\hline & & $\begin{array}{l}\text { Compres- } \\
\text { sive test }\end{array}$ & $f_{\mathrm{c}, \mathrm{cul}}$ & 28,30 & 27,34 \\
\hline \multirow{4}{*}{ iे } & \multirow{4}{*}{$\begin{array}{c}\text { Concrete } \\
\text { strength } \\
\text { weakening } \\
\text { in } 1 / 2 l \\
\text { (middle of } \\
\text { the sample) }\end{array}$} & Non- & $\overline{f_{l}}$ & 32,8 & 38,6 \\
\hline & & destructive & $f_{2}$ & 30,6 & 27,9 \\
\hline & & method & $f_{l}$ & 44,1 & 47,0 \\
\hline & & $\begin{array}{l}\text { Compres- } \\
\text { sive test }\end{array}$ & $f_{\mathrm{c}, \mathrm{cul}}$ & 34,16 & 36,01 \\
\hline \multirow{2}{*}{$\frac{0}{\text { s }^{\prime}}$} & \multirow{2}{*}{$\begin{array}{l}\text { Concrete of } \\
\text { the same } \\
\text { strength } \\
\text { throughout } \\
\text { the height }\end{array}$} & $\begin{array}{c}\text { Non- } \\
\text { destructive } \\
\text { method }\end{array}$ & $f_{3}$ & 32,6 & 32,9 \\
\hline & & $\begin{array}{c}\text { Compres- } \\
\text { sive test }\end{array}$ & $f_{\mathrm{c}, \mathrm{cul}}$ & 32,62 & 32,98 \\
\hline
\end{tabular}

\section{Conclusions}

The paper analyses the influence of technological defects type and parameters on performance of tube confined concrete elements, and determines the minimum damage parameters, the presence of which practically does not affect the performance and bearing capacity of a tube confined concrete element overall.

At the same time, the analysis of the concrete core structure of the experimental tube confined concrete samples indicates the absence of disintegration in the concrete mix and equal distribution of its components along the samples height (with the exception of artificially created defects), the concreting of which took place in an upright position. Thus, we can draw the following conclusions:

1. For elements with artificially created defects (voids) throughout the sample length, formation of longitudinal cracks in the concrete core typically occurs, which is due to the stress concentration and reduces the bearing capacity of the samples to $30 \%$.

2 . Tube confined concrete samples with variable height concrete strength are characterized by more ductile destruction due to overall and local instability. The presence of lower strength concrete in the middle of the sample or loose-fill by $10-35 \%$ reduces the loadbearing capacity of the sample in comparison with the sample without weakening.

3.The most critical type of core defects (abnormalities) are cavities and voids, which reduce the bearing capacity of the tube confined concrete element to $30 \%$ of the calculated value.

4. The main condition for the concrete samples production was the same weight of cement. As a result, the study was conducted on the influence of unequal height strength on the general strength characteristics of the samples. The tests results of concrete sample cylinders showed that for heterogeneous concrete strength the best 
result for strength was typically shown by samples with higher quality of concrete in the middle, which exceeds the strength of the control samples by $9,3 \%$. This tendency is typical for samples with $400 \mathrm{~mm}$ height, and for a more detailed study a similar analysis was performed for samples with $200 \mathrm{~mm}$ height.

5. It was found that the compressive strength of tube confined concrete samples in a steel tube casing is determined by the size, height (length) and strength of their "weak" part. Technical defects in concreting of all samples cause strength decrease to $20 \%$. With the decrease in samples height and size of concrete defects, the fracture pattern and samples strength varies within measurement errors (up to $10 \%$ ). Thus, with the sample size reduction, the influence of the concrete core defects is weakened.

\section{References}

[1] L.I. Storozhenko, O.V. Semko, V.F. Pents, Stalezalizobetonni konstruktsii. Nav-chalnyi posibnyk, Poltava, 181 (2005)

[2] S. De Nardin, , and A. L. H. C. El Debs, Proceedings of the Institution of Civil Engineers - Structures and Buildings, https://doi.org/10.1680/stbu.2007.160.1.13

[3] Ricardo Alfredo Cruz Hernández, Luis Eduardo Zapata Orduz, Luz Amparo Quintero Ortiz, Julián Orlando Herrera Ortiz, Physical and mechanical characterization of concrete exposed to elevated temperatures by using ultrasonic pulse velocity, DOI: 10.17533/udea.redin.n75a12

[4] O.V. Semko Imovirnisni aspekty rozrakhunku stalezalizobetonnykh konstruktsii, Monograph, Kiev, 316 (2004)

[5] Voskobiinyk Olena, Gukasian Olga «Study of technological features of tubular compressed concrete in concreting», MATEC Web of Conferences, Vol.116, No.02037, (2017). DOI: 10.1051/matecconf/20171160203 Transbud-2017 (Scopus) https://www.matec-

conferences.org/articles/matecconf/abs/2017/30/

matecconf_trs2017_02037/matecconf_trs2017_02037.html

[6] S.M.R. Tabatabai, K.M. Mosalam, (2001) "Computational platform for non-linear analysis/ optimal design of reinforced concrete structures", Engineering Computations, Vol. 18 Issue: 5/6, pp.726743, https://doi.org/10.1108/EUM0000000005785

[7] Design of composite steel and concrete structures - Part 1-1: General Rules and Rules for Bridges. EN 1994-1: 2001. Eurocode 4, Brussels, 96 (2006)

[8] O.V. Semko, O.P. Voskobiinyk, Keruvannia ryzykamy pry proektuvanni ta ekspluatatsii stalezalizobetonnykh konstruktsii Monograph, Poltava, 514 (2012)

[9] Bruce Ellingwood Theodore V. Galambos, Probability-based criteria for structural design, https://doi.org/10.1016/01674730(82)90012-1

[10] Tjiang Arif Gunadi, Herman Parung, Abd Rachman Djamaluddin, A Arwin Amiruddin, Design of reinforced areas of concrete column using quadratic polynomials, doi:10.1088/1757 899X/271/1/012098, http://iopscience.iop.org/article/10.1088/1757$899 \mathrm{X} / 271 / 1 / 012098 / \mathrm{pdf}$

[11] Repair and strengthening of concrete structures July 07, 2015 https://doi.org/10.1680/frasocs.16156.fm

[12] Storozhenko, L., Butsky, V., Taranovsky, O. Stability of Compressed Steel Concrete Composite Tubular Columns with Centrifuged Cores // Journal of constructional steel research; 46, 1/3; 484; Second World Conference on Steel in Construction ; 1998.

[13] Piskunov, V.G., Gorik, A.. \& Cherednikov, V.N. Mechanics of $\begin{array}{llll}\text { Composite } \quad \text { Materials } & \text { (2000) } & \text { 36: } & 445\end{array}$ https://doi.org/10.1023/A:1006798314569 